\title{
Autumn migration of Montagu's harriers Circus pygargus tracked by satellite telemetry
}

\author{
Ruben Limiñana $\cdot$ Alvaro Soutullo $\cdot$ Vicente Urios
}

(C) Dt. Ornithologen-Gesellschaft e.V. 2007

\begin{abstract}
Although there is a general understanding of Montagu's harriers migration routes and wintering areas, detailed information on the species' migration is still lacking. However, improvements in satellite tracking technology in recent years, have enabled the study of medium-sized species by means of satellite telemetry. In 2006, ten adult Montagu's harriers were fitted with satellite transmitters in northeastern Spain and tracked during their autumn migration to their wintering grounds in sub-Saharan Africa. The migration took between 10 and 30 days, and the end point was determined using breakpoint regressions. Whereas some birds had stopovers of more than a week, others stayed at the same site for only 1 or 2 days at the most. The tagged birds ultimately established at wintering grounds located along the border of Mauritania with Mali and Senegal, a distance of nearly $3000 \mathrm{~km}$ from the breeding sites. These sites are situated within a small range of latitudes $\left(14^{\circ}\right.$ and $\left.17^{\circ} \mathrm{N}\right)$, although distributed over a wider range of longitudes $\left(-15^{\circ} \mathrm{E}\right.$ and $\left.-4^{\circ} \mathrm{E}\right)$, with some birds occupying sites more than $1000 \mathrm{~km}$ apart. The distance covered in 1 day during the migration ranged between 93 and $219 \mathrm{~km}$, with peaks of traveling speed of up to $65 \mathrm{~km} / \mathrm{h}$. Harriers were recorded traveling only during daytime, covering the longest distances in the late afternoon, suggesting that they are daytime migrants. Most of the distance was covered between 1500 and 2000 hours, and no traveling was recorded between 2000 and 0500
\end{abstract}

Communicated by A. Hedenström.

R. Limiñana $(\square) \cdot$ A. Soutullo $\cdot$ V. Urios

Estación Biológica Terra Natura

(CIBIO, Fundación Terra Natura),

Universidad de Alicante, Apdo. Correos 99,

Alicante 03080, Spain

e-mail: ruben.lm@gmail.com hours. During migration, harriers flew close to the ground (40-100 $\mathrm{m}$ on average). Improved knowledge of the harriers' exact wintering sites may provide insights on the problems Montagu's harriers face during the winter, highlighting the need to take into account what happens in both the breeding and wintering grounds to implement successful conservation measures.

Keywords Circus pygargus - Migration routes . Satellite tracking $\cdot$ Wintering grounds

\section{Introduction}

The Montagu's harrier (Circus pygargus) is a long-distance migrant which breeds over large areas within Europe and western Asia and spends the winter in sub-Saharan Africa (Cramp and Simmons 1980; Clarke 1996). Females typically first reproduce during their second year and males during their third year, with young birds staying in the wintering grounds before traveling to breed (Cramp and Simmons 1980; Clarke 1996). It is generally assumed that populations breeding in Western Europe overwinter in Western Africa, those breeding in Eastern Europe spend the winter in East Africa, and those breeding in Asia presumably travel to Sri Lanka and the Indian subcontinent during the winter (Clarke 1996). Nonetheless, data on the exact winter distribution of European Montagu's harriers in Africa are scarce.

A partially circular migration route has been proposed for Montagu's harriers breeding in Europe (Agostini and Logozzo 1997; García and Arroyo 1998), with most of the birds crossing the Gibraltar Strait during their autumn migration to Africa and traveling through the central region of the Mediterranean during their return migration to 
European breeding areas. However, to date, most of the results reported on the migratory movements of Montagu's harriers are based on observational data at bottleneck points (Bernis 1980; Finlayson 1992; Shirihai and Christie 1992; Corso 2001; Panuccio et al. 2005; Panuccio and Agostini 2006) or on data recovered from ringing studies (see García and Arroyo 1998 for a review), and detailed knowledge of the migration routes of this species as well as individual differences is still lacking.

During the last decade, satellite telemetry has enabled detailed tracking of bird movements (Kenward 2001; McGrady et al. 2003; Cadahía et al. 2005; Soutullo et al. 2006a, b, c), particularly migration (Berthold et al. 1995; Fuller et al. 1995; Meyburg et al. 1995, 1998; Hake et al. 2001, 2003; Kjellén et al. 2001; Ganusevich et al. 2004; Judas et al. 2006), resulting in the identification of wintering grounds and the mapping of migration routes (see Guan and Higuchi 2000 for a review). Although satellite telemetry has been mostly used in large bird species to date, the development of smaller transmitters now allows the use of this technology with lighter species (Soutullo et al. 2007).

We report here an account of the movement of Montagu's harriers during the autumn migration. Birds were tracked from their breeding grounds in the Iberian Peninsula to their wintering grounds in West Africa using satellite telemetry. Data on migration routes and timing are provided. We also have developed a new method to estimate the end of the migration based on satellite telemetry data. As birds tracked by satellite telemetry are not followed in the field, key moments during their yearly cycle must be inferred from an analysis of the spatial pattern of locations, with location accuracy being far from perfect. The use of standardized procedures to estimate the dates at which key events take place is thus of utmost importance, and we expect that the method we present here will also be useful for the study of other species.

\section{Methods}

The Montagu's harriers (Circus pygargus) tracked in this study were captured in the province of Castellon, northeastern Spain. In this area, birds breed in a typical sclerophyllous Mediterranean shrubland (Limiñana et al. 2006a, b). The population has been monitored since it first established there in the early 1980s and shows some of the highest productivity values recorded for the species (see Limiñana et al. 2006a, b; Soutullo et al. 2006d).

Ten adult Montagu's harriers (six males and four females) were captured between May and June 2006 using dho-gaza nets (Bub 1991) and a stuffed Eagle Owl (Bubo bubo) as a decoy. Captured birds were sexed (based on the pattern of colors of the plumage), weighed, and ringed, and a Microwave Telemetry's $9.5 \mathrm{~g}$ solar-powered PTT-100 platform transmitter terminal (PTT) was affixed to their backs using a Teflon harness (see Kenward 2001; Cadahía et al. 2005; Soutullo et al. 2006b). The birds were released within 30 min of capture. For the first 3 months of operation, the PTTs were programmed on a $6 \mathrm{~h}$ on/16 h off duty cycle; for the subsequent months, the duty cycle consisted of $10 \mathrm{~h}$ on/56 $\mathrm{h}$ off. Locations were collected using the Argos system, and in this study we analyze data collected up to 17 October 2006, at which time the birds were already at their wintering grounds and movements were restricted to short-distance local flights. All data were retrieved and managed using STAT, the Satellite tracking and analysis tool (Coyne and Godley 2005).

Argos assigns a measure of reliability (LC) to each position estimate. Only locations assigned to LCs 3, 2, 1, and 0 were used for the analyses, as these are the most reliable ones (see Soutullo et al. 2007 and references therein). Also, to avoid biases associated to the non-independence of the data, positions obtained less than $1 \mathrm{~h}$ after the previous one were excluded from the analyses. Due to the small sample size no between-sexes comparisons were undertaken.

The onset of the migration was determined on the basis of an abrupt change in the pattern of movements undertaken by harriers after the pre-migration phase (Limiñana et al., in preparation). To estimate the date of the end of the migration, we conducted breakpoint (piecewise) regressions (Neter et al. 1985) using all the data collected from the date of the onset of the migration onwards. In order to ensure enough data points were available for the analysis, for bird 39706, the last one to depart from the breeding grounds, we used data for the whole month of October to calculate the regression (as we did for all of the other birds, for the rest of the analyses we only used data collected up to the end date of 17 October). Regressions were conducted using the non-linear estimation module of the package Statistica (Statsoft, Tulsa, Okla). One breakpoint was calculated using the following regression:

$$
\begin{aligned}
& \text { Date }=\text { Constant }+ \text { Slope } 1 \times \text { Distance }+ \text { Slope } 2 \\
& \quad \times(\text { Distance }- \text { Breakpoint }) \times(\text { Distance }>\text { Breakpoint })
\end{aligned}
$$

with Date indicating the day of the year the location was obtained, Distance indicating the distance from the corresponding location to the site where the harrier was marked. Distance $>$ Breakpoint assumed a value of 1 or 0 depending on whether the inequality was true or false, respectively.

The constant and slopes were estimated using the QuasiNewton method (which uses the second-order derivatives 
of the loss function to guide the search for the best parameter estimates), with an improvement in the loss function $<0.0001$ as the convergence criterion, and (observed - predicted $)^{2}$ as the loss function. Initial values for Constant and Breakpoint were the date of the onset of the migration and 2500, respectively. For the breakpoint, this value roughly corresponds to the distance from the breeding site to the southern limit of the Sahara desert. The date of the end of the migration was considered to be the first date the bird was located beyond the breakpoint.

Using these data we calculated the duration of the migration, the distance covered during the migration, and the average and maximum (distance between locations obtained in consecutive days with approx. $24 \mathrm{~h}$ of difference) distance covered in a day, distance covered in $1 \mathrm{~h}$ (considering only locations obtained with less than $4 \mathrm{~h}$ of difference), and above-ground altitude at which birds were located. The latter parameter was calculated by subtracting the height of the terrain from the altitude calculated by Argos for the PTTs. We obtained the height of the terrain at each location from Google Earth (http://www.earth.google.com). To explore differences in the "speed" (distance/ h) at which the birds flew at different times of the day, we conducted linear and quadratic regressions of "speed" against time. All statistical analyses were conducted in SPSS (SPSS, Chicago, Ill.).

\section{Results}

At least six of the ten birds fitted with a PTT completed their migration from the breeding grounds in northeastern Spain to West Africa: three males and three females. No data were obtained for one of these six birds during the migration (we only have locations in the breeding and wintering grounds). Four birds either died or the transmitter failed, two before starting the migration and two during it. Hence, only five individuals were tracked throughout the whole migration. However, even with the tracking technology used, given the low frequency of locations, it is uncertain whether all five birds crossed to Africa from southern Spain over the Gibraltar Strait (Fig. 1). The birds followed different migration routes, and while some had stopovers of more than 1 week, others stayed at the same site for only 1 or 2 days at the most (Fig. 2). Most movements were recorded in the afternoon, with a peak between 1500 and 2000 hours in terms of distances flown in $1 \mathrm{~h}$ (Fig. 3).

Table 1 shows the results of the breakpoint analysis. The harriers started the migration in late July-August, and covered the approximately $2500 \mathrm{~km}$ of the migration in 10-30 days, with distances covered in any 1 day oscillating around 100-200 km (Table 2). In general, the birds flew

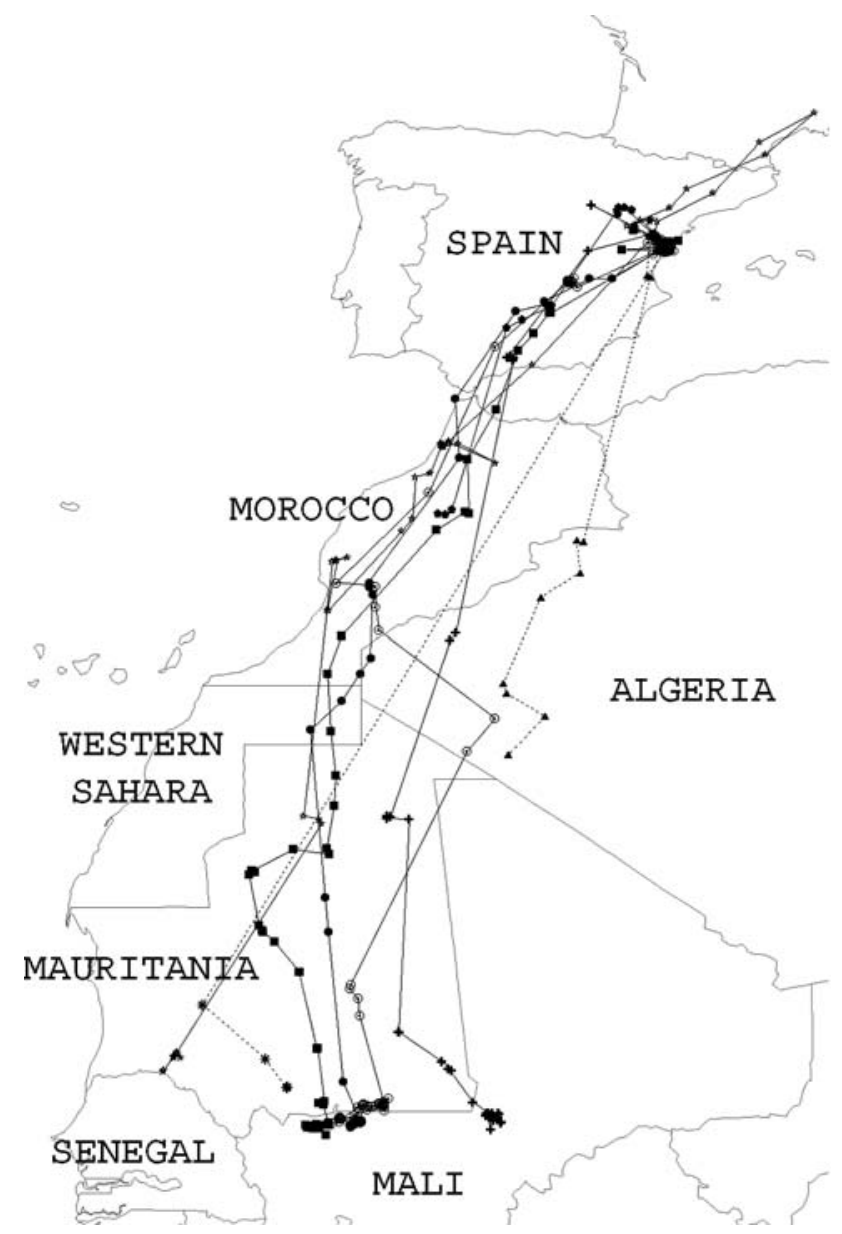

Fig. 1 Migration routes of eight adult Montagu's harriers tracked with satellite telemetry. Dashed lines indicate birds for which scarce satellite data were received during the migration

near the ground (0-210 m, with only one record above this, of $608 \mathrm{~m}$, shortly after having passed over the Atlas Mountains). Harriers descended to sea level while crossing the Mediterranean Sea (around $35^{\circ} \mathrm{N}$ ), and ascended to approximately $2000 \mathrm{~m}$ while crossing the Atlas Mountains (Morocco, $32-30^{\circ} \mathrm{N}$ ).

\section{Discussion}

This study provides an account of the autumn migration of Montagu's harriers from their breeding grounds in Western Europe to their wintering grounds in West Africa. This study was only possible because of recent improvements in satellite telemetry technology and the release at the end of 2005 of lightweight PTTs of less than $10 \mathrm{~g}$ (Soutullo et al. 2007).

Montagu's harriers migrating from northeastern Spain showed a great variation in the timing of the migration and the routes they followed. While the first bird started the 
Fig. 2 Progressive distancing from tagging site of seven migrating Montagu's harriers. Data for bird 39711 are not shown because no location was obtained during the migration
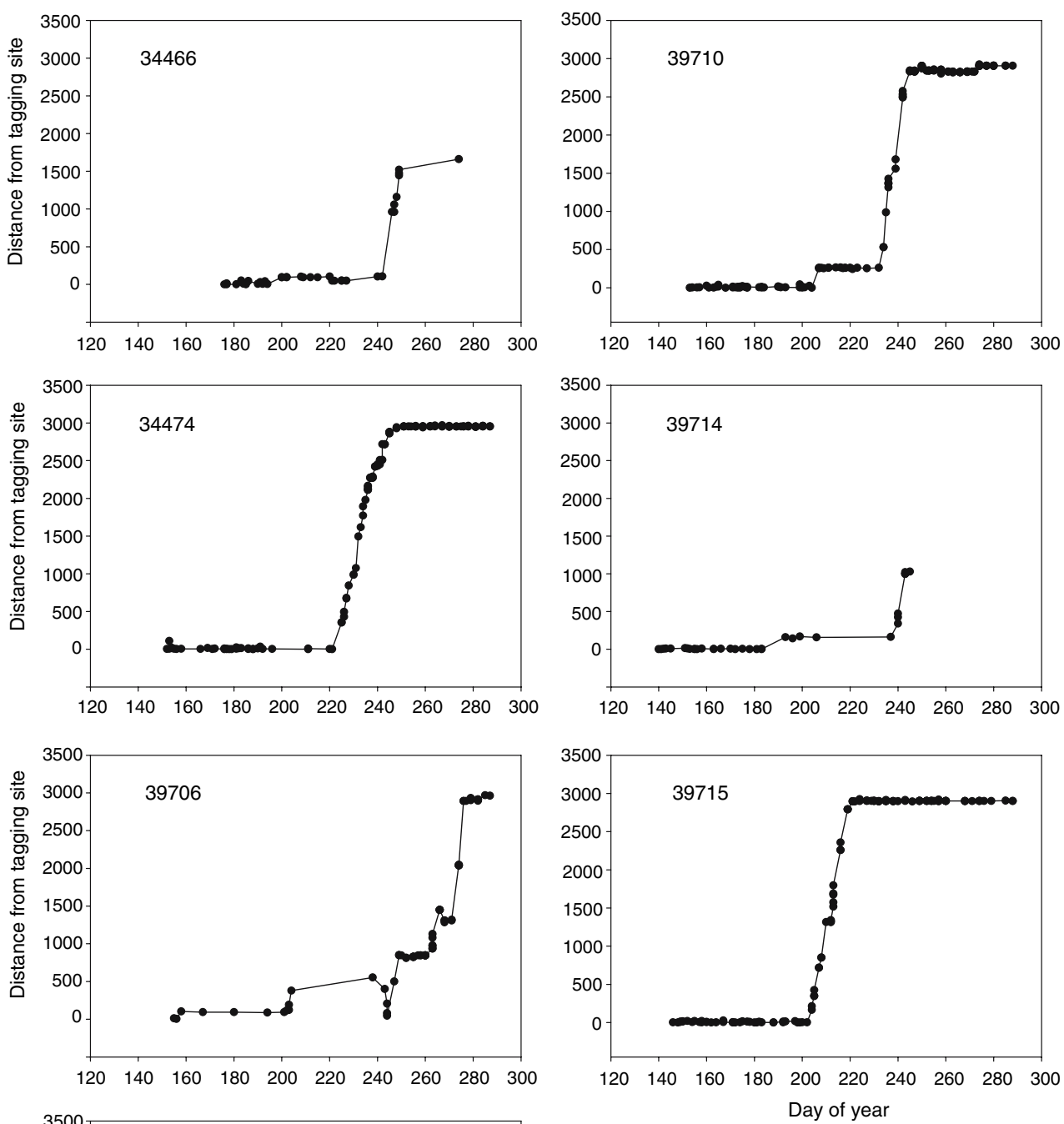

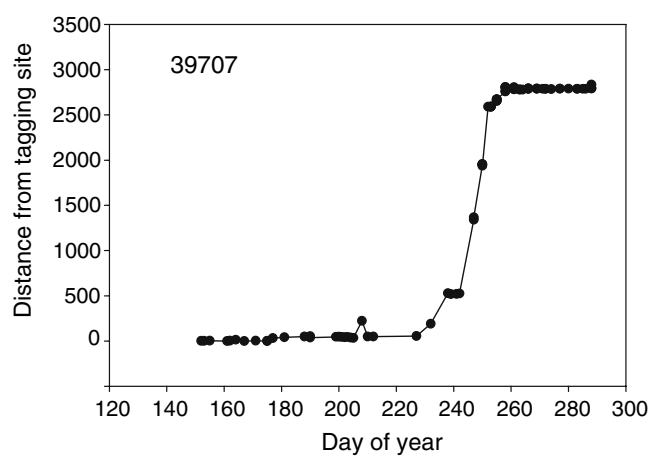

migration on 25 July, the last one left on 3 September. The duration of the complete migration traject varied between 10 and 30 days, resulting in large differences in the date of arrival at the wintering grounds (7 August-2 October). Although some of this variation may be due to between-sex differences in behavior (see Table 2), the small sample size precludes further analyses. Overall, the whole distance covered during the migration ranged between 2200 and $3000 \mathrm{~km}$. After migration, all harriers settled in areas located within a small range of latitudes $\left(14^{\circ}\right.$ and $\left.17^{\circ} \mathrm{N}\right)$. However, these sites are distributed over a wider range of longitudes $\left(-15^{\circ}\right.$ and $\left.-4^{\circ} \mathrm{E}\right)$, with some birds occupying places more than $1000 \mathrm{~km}$ apart. This distribution may partially reflect the distribution of locusts during the winter, the main prey of Montagu's harriers in Africa (Cormier and Baillon 1991; Arroyo et al. 1995), as while wintering, Montagu's harriers are apparently less generalists than during the breeding season (e.g., Underhill-Day 1993; Arroyo 1997). 


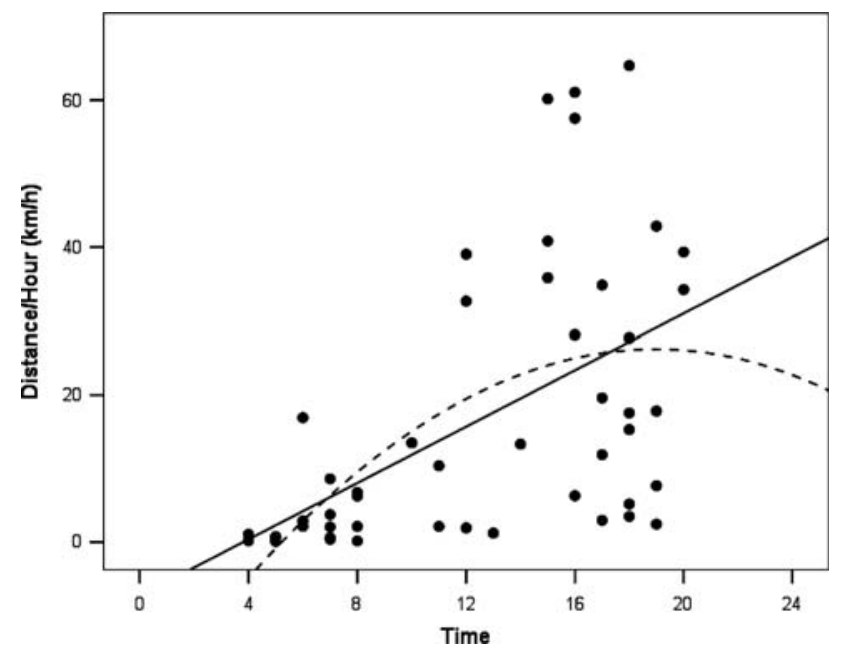

Fig. 3 Linear (distance $/ \mathrm{h}=-7.31+1.92 \times$ time, $\quad F_{1,46}=18.41$; $p<0.0001 ; R^{2}=0.286$ ) and quadratic (distance $/ \mathrm{h}=-23.74+$ $5.27 \times$ time $-0.14 \times$ time $\left.^{2}, \quad F_{2,45}=9.88 ; p<0.0001 ; R^{2}=0.305\right)$ relationships between traveling speed $(\mathrm{km} / \mathrm{h})$ and time of the day in five migrating Montagu's harriers

Table 1 Coefficients of the breakpoint regressions conducted to determine the end of the migration period of five Montagu's harriers

\begin{tabular}{lllllll}
\hline PTT-ID & Constant & Slope 1 & Breakpoint & Slope 2 & $n$ & $R^{2}$ \\
\hline 34474 & 221.736 & 0.007 & $2,910.036$ & 0.560 & 82 & 0.79 \\
39706 & 247.583 & 0.012 & $2,893.235$ & 0.063 & 48 & 0.9 \\
39707 & 240.192 & 0.005 & $2,668.937$ & 0.140 & 43 & 0.56 \\
39710 & 230.038 & 0.005 & $2,747.818$ & 0.178 & 68 & 0.58 \\
39715 & 203.803 & 0.005 & $2,783.806$ & 0.230 & 75 & 0.43 \\
\hline
\end{tabular}

Although all marked harriers reached Africa through southern Spain, it is uncertain whether all individuals crossed over the Gibraltar Strait. Interestingly, the tracked harriers in our study were recorded traveling only during the daytime, covering the longest distances in the late afternoon, suggesting that they are mainly daytime migrants. In contrast, Spaar and Bruderer (1997) recorded Montagu's harriers starting their sea crossing just before sunrise and after sunset, suggesting that they also fly during the night (see also Meyer et al. 2003). Shortly after crossing the Mediterranean Sea, harriers need to gain altitude to cross the Atlas Mountains and probably take advantage of the height gained during the ascent to advance a long distance during the first stage of the desert crossing (records of more than $450 \mathrm{~km}$ in a day). Their daily speed seems to drop after that, as it may take up to 2 weeks to cover the remaining $1000-1500 \mathrm{~km}$ to the wintering grounds, with average distances covered in 1 day ranging between 93 and $219 \mathrm{~km}$. Thus, in contrast with other species that perform long and high-altitude journeys during night time without stopping, our Montagu's harriers tended to remain close to the ground, flew during the daytime and extended the migration for up to 1 month. The flight close to the ground seems to confirm that the species feeds along the migratory route as well as mostly uses flapping flight during migration over land (Spaar and Bruderer 1997).

The method we present here provides a mathematically explicit approach for estimating the date of the end of the migration. As estimates are obtained applying a standardized method, they can be readily compared with those obtained in other studies or with other species using the same technique. One of the main limitations when analyzing satellite telemetry data is that as animals are not observed in the field, key stages in their life cycle must be inferred from the spatial pattern of the locations collected (e.g., Soutullo et al. 2006c). Piecewise regressions are a standard technique used in time-series analysis to detect patterns in temporal data (e.g., Chatfield 2004). Their application to the study of migration using satellite telemetry (which basically consists in the analysis of temporal series of locations) is hence straightforward. One advantage of using piecewise regressions is that the models used to describe the movements may be tailored to account for different movement patterns, including non-linear relationships between date and distance and more than one breakpoint. For example, the movements of species that make long stopovers might be better described using more than one breakpoint. The main limitation to accurately estimate the unknown parameters is probably the number of available locations before and after the breakpoints. This is probably more relevant when the relationship between date and distance is not smooth, and explains why we had to extend for 2 weeks the time-period analyzed to estimate the regression parameters of the last individual to depart from the breeding grounds (see Fig. 2. individual 39706). The question remains as to how this method would fare for species showing different movement patterns. We therefore invite researchers using satellite telemetry data to apply this or other mathematically explicit methods when determining the timing of key stages in the life cycle of the animals under study instead of using more subjective approaches that preclude rigorous comparisons.

\section{Zusammenfassung}

Satelliten-Telemetrie von Wiesenweihen (Circus pygargus) auf dem Herbstzug

Wenngleich die Zugrouten und Überwinterungsgebiete der Wiesenweihe generell bekannt sind, fehlen immer noch detaillierte Kenntnisse zum Zugverhalten dieser Art. Seit wenigen Jahren ermöglichen Verbesserungen in der Technik der Satelliten-Telemetrie ihre Verwendung auf 
mittelgroßen Vogelarten. Im Jahr 2006 haben wir 10 adulte Wiesenweihen in Nordost-Spanien mit Satellitensendern ausgerüstet und sie auf ihrem Herbstzug nach Afrika südlich der Sahara verfolgt, der zwischen 10 und 30 Tage dauerte. Das Ende des Zuges wurde mit Hilfe einer Breakpoint-Regression bestimmt. Während einige Vögel Zwischenstopps von über einer Woche einlegten, blieben andere kaum länger als ein oder zwei Tage am selben Ort. Nach Beendigung des Zugs hielten sich die telemetrierten Vögel im Grenzgebiet von Mauretanien mit Mali und Senegal auf, ungefähr $3000 \mathrm{~km}$ von ihren Brutplätzen entfernt. Die Winterquartiere liegen in einem schmalen Gürtel zwischen $14^{\circ}$ und $17^{\circ}$ nördlicher Breite, jedoch breit gestreut im Bereich zwischen $-15^{\circ}$ und $-4^{\circ}$ östlicher Länge, wobei einige Vögel mehr als $1000 \mathrm{~km}$ weit entfernt überwinterten. Die pro Tag zurückgelegte Strecke betrug zwischen 93 und $219 \mathrm{~km}$, mit Reise-Spitzengeschwindigkeiten von bis zu $65 \mathrm{~km} / \mathrm{h}$. Zugbewegung ließ sich bei den Weihen nur am Tag feststellen, und die längsten Strecken legten die Vögel am späten Nachmittag zurück, was den Schluss zulässt, das sie reine Tagzieher sind. Die meisten Ortsveränderungen traten zwischen 15:00 und 20:00 Uhr auf, und zwischen 20:00 und 5:00 Uhr wurde keinerlei Bewegung festgestellt. Auf dem Zug flogen die Weihen bodennah (im Durchschnitt 40-100 Meter hoch). Die genaue Kenntnis der Überwinterungsgebiete gibt womöglich Einblicke in die Probleme, mit denen die Wiesenweihen im Winter konfrontiert sind. Hervorgehoben werden soll damit, wie notwendig es ist, die Geschehnisse in den Brut- und Überwinterungsgebieten gleichermaßen zu betrachten, um erfolgreiche Schutzmaßnahmen durchführen zu können.

Acknowledgements The satellite tracking study of Montagu's harrier in Castellon is fully funded by Aeropuerto de Castellón. We are grateful to Conselleria de Territori I Habitatge (Generalitat Valenciana) for providing the necessary permission for tagging harriers, especially to Juan Jiménez and Martín Surroca. Beatriz Arroyo, Keith Bildstein and an anonymous referee improved a previous draft of the manuscript. The first author has a grant from Generalitat Valenciana; this paper is part of his $\mathrm{PhD}$ thesis at the Universidad de Alicante. Tagging of individuals comply the current laws of Spain.

\section{References}

Agostini N, Logozzo D (1997) Autumn migration of Accipitriformes through Italy en route to Africa. Avocetta 21:174-179

Arroyo BE (1997) Diet of Montagu's Harrier Circus pygargus in central Spain: analysis of temporal and geographical variation. Ibis 139:664-672

Arroyo B, King JR, Palomares LE (1995) Obsevations on the ecology of Montagu's and Marsh harriers wintering in northwest Senegal. Ostrich 66:37-39

Bernis F (1980) La migración de las aves en el Estrecho de Gibraltar, vol 1. Aves planeadoras. Universidad Complutense, Madrid 
Berthold P, Nowak E, Querner U (1995) Satelliten-Telemetrie eines Zugvogels von Mitteleuropa bin in das südafrikanische Winterquartier eine Fallstudie am Weis-storch (Ciconia ciconia). J Ornithol 136:73-76

Bub H (1991) Bird trapping and bird banding. Cornell University Press, Ithaca

Cadahía L, Urios V, Negro JJ (2005) Survival and movements of satellite tracked Bonelli's eagles during their first winter. Ibis 147:415-419

Chatfield C (2004) The analysis of time series. An introduction, 6th edn. Chapman \& Hall/CRC, Boca Raton

Clarke R (1996) Montagu's Harrier. Arlequin, Chelmsford

Cormier JP, Baillon F (1991) Concentrations de busards cendres Circus pygargus dans la region de M'Bour (Senegal) durant l'hiver 1988-1989: utilisation du milieu et regime alimentaire. Alauda 59:163-168

Corso A (2001) Raptor migration across the Strait of Messina, southern Italy. Br Birds 94:196-202

Coyne MS, Godley BJ (2005) Satellite tracking and analysis tool (STAT): an integrated system for archiving, analyzing and mapping animal tracking data. Mar Ecol Prog Ser 301:1-7

Cramp S, Simmons KEL (1980) The birds of the Western Paleartic, vol 2. Oxford University Press, Oxford

Finlayson C (1992) Birds of the Strait of Gibraltar. T \& AD Poyser, London

Fuller MR, Seegar WS, Howey PW (1995) The use of satellite telemetry systems for the study of bird migration. Isr J Zool 41:243-252

Ganusevich SA, Maechtle TL, Seegar WS, Yates MA, McGrady MJ, Fuller M, Schueck L, Dayton J, Henny CJ (2004) Autumn migration and wintering areas of Peregrine Falcons Falco peregrinus nesting oh the Kola Peninsula, northern Russia. Ibis 146:291-297

García JT, Arroyo BE (1998) Migratory movements of Montagu's harriers Circus pygargus: a review. Bird Study 45:188-194

Guan HL, Higuchi H (2000) Review on satellite tracking of migratory birds and its prospect. Zool Res 21:412-415

Hake M, Kjellén N, Alerstam T (2001) Satellite tracking of Swedish Ospreys Pandion haliaetus: autumn migration routes and orientation. J Avian Biol 32:47-56

Hake M, Kjellén N, Alerstam T (2003) Age-dependent migration strategy in honey buzzards Pernis apivorus tracked by satellite. Oikos 103:385-396

Judas J, Combreau O, Lawrence M, Saleh M, Launay F, Xingy G (2006) Migration and range use of Asian Houbara Bustard Chlamydotis macqueenii breeding in the Gobi desert, China, revealed by satellite tracking. Ibis 148:343-351

Kenward RE (2001) A manual for wildlife radio tagging. Academic, London

Kjellén N, Hake M, Alerstam T (2001) Timing and speed of migration in male, female and juvenile Ospreys Pandion haliaetus between Sweden and Africa as revealed by field observations, radar and satellite tracking. J Avian Biol 32:5767
Limiñana R, Surroca M, Miralles S, Urios V, Jiménez J (2006a) Population trend and breeding biology of Montagu's Harrier Circus pygargus in a natural vegetation site in northeast Spain. Bird Study 53:126-131

Limiñana R, Soutullo A, Urios V, Surroca M (2006b) Vegetation height selection in Montagu's harriers Circus pygargus breeding in a natural habitat. Ardea 94:280-284

McGrady MJ, Ueta M, Potapov E, Utekhina I, Masterov V, Ladyguine A, Zykov V, Cibor J, Fuller M, Seegar WS (2003) Movements by juvenile and immature Steller's sea eagles Haliaeetus pelagicus tracked by satellite. Ibis 145:318-328

Meyburg BU, Eichaker X, Meyburg C, Paillat P (1995) Migrations of an adult spotted eagle tracked by satellite. Br Birds 88:357-361

Meyburg B-U, Meyburg C, Barbraud JC (1998) Migration strategies of an adult short-toed eagle Circaetus gallicus tracked by satellite. Alauda 66:39-48

Meyer SK, Spaar R, Bruderer B (2003) Sea crossing behaviour of falcons and harriers at the southern mediterranean coast of Spain. Avian Sci 3:153-162

Neter J, Wasserman W, Kutner MH (1985) Applied linear statistical models: regression, analysis of variance, and experimental designs. Irwin, Homewood

Panuccio M, Agostini N (2006) Spring migration of Pallid (Circus macrourus) and Montagu's harriers (Circus pygargus) in relation to sex and age classes at two watchsites of the central mediterranean. Buteo 15:3-10

Panuccio M, Agostini N, Mellone U (2005) Autumn migration strategies of honey buzzards, black kites, marsh and Montagu's harriers over land and over water in the central mediterranean. Avocetta 29:27-32

Shirihai H, Christie DA (1992) Raptor migration in Eilat. Br Birds $85: 141-186$

Soutullo A, Urios V, Ferrer M (2006a) How far away in an hour? daily movements of juvenile golden eagles (Aquila chrysaetos) tracked with satellite telemetry. J Ornithol 147:69-72

Soutullo A, Urios V, Ferrer M, Peñarrubia SG (2006b) Dispersal of golden eagles Aquila chrysaetos during their first year of life. Bird Study 53:258-264

Soutullo A, Urios V, Ferrer M, Peñarrubia SG (2006c) Post-fledging behaviour in golden eagles: onset of the juvenile dispersal and progressive distancing from the nest. Ibis 148:307-312

Soutullo A, Limiñana R, Urios V, Surroca M, Gill JA (2006d) Density-dependent regulation of population size in colonial breeders: Allee and buffer effects in the migratory Montagu's harrier. Oecología 149:543-552

Soutullo A, Cadahía L, Urios V, Ferrer M, Negro JJ (2007) Accuracy of lightweight satellite telemetry: a case study in Iberian Peninsula. J Wildl Manage 71:1010-1015

Spaar R, Bruderer B (1997) Migration by flapping or soaring: flight strategies of marsh, Montagu's and pallid harriers in southern Israel. Condor 99:458-469

Underhill-Day JC (1993) The foods and feeding rates of Montagu's harriers Circus pygargus breeding in arable farmland. Bird Study 40:74-80 